\section{UCDNN}

LIBRARY
University of Connecticut OpenCommons@UConn

Faculty Articles and Papers

School of Law

1971

\title{
The Neutrality of Adherence to Precedent
}

Robert Birmingham

University of Connecticut School of Law

Follow this and additional works at: https://opencommons.uconn.edu/law_papers

Part of the Jurisprudence Commons, and the Law and Philosophy Commons

\section{Recommended Citation}

Birmingham, Robert, "The Neutrality of Adherence to Precedent" (1971). Faculty Articles and Papers. 86.

https://opencommons.uconn.edu/law_papers/86 


\section{HEINONLINE}

Citation: 1971 Duke L.J. 5411971

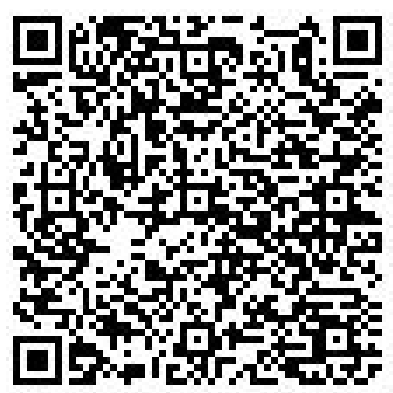

Content downloaded/printed from

HeinOnline (http://heinonline.org)

Mon Aug 15 16:44:26 2016

-- Your use of this HeinOnline PDF indicates your acceptance of HeinOnline's Terms and Conditions of the license agreement available at http://heinonline.org/HOL/License

-- The search text of this PDF is generated from uncorrected OCR text.

-- To obtain permission to use this article beyond the scope of your HeinOnline license, please use:

https://www.copyright.com/ccc/basicSearch.do?

\&operation $=$ go\&search $\mathrm{Type}=0$

\&lastSearch $=$ simple\&all=on\&titleOrStdNo=0012-7086 


\title{
THE NEUTRALITY OF ADHERENCE TO PRECEDENT
}

\author{
ROBERT L. BIRMINGHAM*
}

Bad law is better than no law, because it establishes uniformity. If you divide money or cattle by drawing lots, it does not follow that such drawing makes a fair division, but disputes will thus be avoided. $\uparrow$

One tradition of law in China insisted that an emperor ideally governed by setting an example for others through living virtuously himself. ${ }^{1}$ His conduct was thought to provide a model for the conduct of his subjects not only with respect to social but also with respect to aesthetic concerns. Imperial appreciation of works of art, a duty often pursued with an indiscriminate enthusiasm which lesser men could hardly emulate, was typically celebrated by affixing a seal and perhaps an inscription to the object admired. Since some rulers were particularly indefatigable observers and since the tastes of successive rulers as well as of other connoisseurs who similarly recorded their experiences were not widely disparate, the seals and inscriptions superimposed on many of the more prestigious older paintings obscure much if not most of the beauty to which these markings presume to attest. ${ }^{2}$

More than a decade ago Professor Wechsler argued that constitutional adjudication should be evaluated primarily in terms of the neutrality of the principles on which the decisions are based. ${ }^{3}$ The response to his argument is reminiscent of, if not so reverential as, the reception accorded works of art in China. His initially elusive contribution has been additionally obscured by the mass of commentary concerning it. ${ }^{4}$ However, the continuing discussion of

* Associate Professor of Law, Indiana University School of Law. A.B., University of Pittsburgh, J.D., 1963, Ph.D., 1967; LL.M., Harvard Law School, 1965.

$\dagger$ Hsün Tzu (320-235 B.C.), quoted in Tsao, Equity in Chinese Customary Law, in Essays in JuRisprudence in HoNor of RosCoe Pound 21, 23 n.4 (R. Newman ed. I962).

1. D. Bodde \& C. Morris, Law in Imperial China 17-23 (1967); T. Ch'tj, LaW aNd SOCIETY IN TRADitional China 253-56 (196I).

2. K. Latourette, The Chinese: Their History and Culture 623 (4th ed. 1964); Sullivan, The Heritage of Chinese Art, in The Legacy of China 165, 211 (R. Dawson ed. 1964). Chinese history is nevertheless not an unrelieved chronicle of cultural enlightenment. See D. BLOODWORTH, The Chinese LOOKING Glass 37 (1967).

3. Wechsler, Toward Neutral Principles of Constitutional Law, 73 HARV. L. REv. I (1959) [hereinafter cited as Principles].

4. The concept of neutrality that he introduced has been repeatedly attacked as unintelligible: Professor Wright, finding it the product of theories more misleading than 
and frequent approving references to the concept of neutral principles demonstrate the existence of a core of meaning offering important insights into the judicial process. One feels that the proposed standard has significance; the problem is to isolate and explicate those elements embedded in the analysis of Professor Wechsler which are responsible for this significance.

In this paper I seek to explore one aspect of the standard proposed by Professor Wechsler through examination of an often remarked interrelationship between this standard ${ }^{5}$ and those values which support adherence to precedent. In my analysis I apply and evaluate a criterion paralleling that which would renounce the legitimacy of value choices in an adjudicatory context; here, however, the argument is inverted. The criterion is taken to supply a sufficient rather than a necessary condition of neutrality. My reasoning, in part involving the role of precedent without reference to the concerns of Professor Wechsler, is grounded on distinctions generated in the theory of games, a branch of mathematics of increasing importance in economics and other social sciences. ${ }^{6}$

enlightening, posits confusion and incorrectness. Wright, The Supreme Court Cannot be Neutral, 40 Tex. L. Rev. 599 (1962). Professor Countryman attributes his inability to understand to what he describes as an intense lack of definition. Countryman, The Constitution and Job Discrimination, 39 WASH. L. REv. 74, 75-76 (1964). Professor Pollak appears willing to proclaim either innocuity or incomprehensibility but uncertain as to which pronouncement is appropriate. Pollak, Racial Discrimination and Judicial Integrity: A Reply to Professor Wechsler, 108 U. PA. L. REv. 1, 34 (1959). See also Pollak, Constitutional Adjudicatlon: Relative or Absolute Neutrality, Il J. PUB. L. 48, 55 (1962).

5. The standard of neutrality has been interpreted to deny the propriety of judicial decisions resulting from choice among competing values. At most this interpretation receives uncertain support from the pronouncements of the progenitor of the concept: although his position has not been unambiguous, Professor Wechsler apparently contended in his initial exposition that judges must make value choices and has subsequently affirmed this claim. Principles 15; see H. WeChsler, Principles, Politics, and Fundamental Law xiii (1961); Wechisler, The Courts and the Constitution, 65 Colum. L. Rev. 1001, 1013-14 (1965). That doubt remains appears in large part a consequence of the absence of plausihle alternative interpretations: the distinction between value judgments and other judgments, while not always clear, permits at least a modicum of classificatory precision; on the other hand, differentiation between acceptable and unacceptable value judgments appears necessarily to depend on individual preference or arbitrary rule.

6. In another paper the author introduced aspects of the theory of games to explain the relationship which Professor Wechsler and others perceive between the standards of neutrality and generality. See Birmingham, The Generality of Neutral Principies: A Game-Theoretic Perspective, 58 Calif. L. Rev. 873 (1970). 


\section{NEUTRALITY AND PRECEDENT}

In his discussion of neutrality Professor Wechsler stated that Brown v. Board of Education ${ }^{7}$ and parallel decisions prohibiting the white primary ${ }^{8}$ and preventing enforcement of racially restrictive covenants $^{9}$ were more likely to yield enduring advantage to the community than were other recent rulings of the Supreme Court. Yet he argued that these cases achieved desirable results only by abandoning that reasoned exposition of the law thought indispensably associated with judicial resolution of disputes. His dissatisfaction appears to be a consequence of an inability to assign priority to one of two competing associational claims-he criticized these decisions because they fail objectively to justify imposition of association on those who would avoid it rather than denial of association to those who would embrace it. ${ }^{10}$

The Court in Plessy v. Ferguson ${ }^{11}$ approved separation of the races so long as the members of each race were treated equally. In Brown the Court partially repudiated Plessy by explicitly rejecting language in this earlier decision inconsistent with its conclusion that separate schooling is psychologically injurious to black children. Arguably it did much more; however, even here the Court might have asserted a perhaps implausible historical continuity by stressing the extent to which its holding may be interpreted as merely an application of the separate but equal standard thought controlling in Plessy. ${ }^{12}$ Scholars have sought to discount the deficiencies of Brown by finding in this or in other ways that a neutrality unrecognized by Professor Wechsler arises from the consistency of this decision with prior rulings of the Court.

In Sweatt v. Painter ${ }^{13}$ and McLaurin v. Oklahoma State

7. 347 U.S. 483 (1954).

8. Smith v. Allwright, 321 U.S. 649 (1944).

9. Barrows v. Jackson, 346 U.S. 249 (1953).

10. Principles 34.

11. 163 U.S. 537 (1896).

12. Perhaps aberrational, Plessy assumed the constitutionality of the dual school system but directly involved only segregation in transportation. 163 U.S. at 544 . Brown, the basis of broader per curiam rulings, purported to decide only that separate institutions were constitutionally insufficient in the field of public education regardless of their physical equivalence. 347 U.S. at 495 . For remarks concerning the relationship between these cases see A. Bickel, The Suprende Court AND the ldea of Progress 4 (1970); Pollak, supra note 4, at 29. But cf. Gong Lum v. Rice, 275 U.S. 78 (1927).

13. 339 U.S. 629 (1950). 
Regents ${ }^{14}$ integration of graduate facilities was compelled in part because equality of education was defined in terms of opportunity for contact with members of the professionally and socially dominant race. While these cases do not announce the holding in Brown, they may be read to impose conditions of equality sufficiently stringent in practice to preclude separate schooling. They thus provide a foundation for the assertion that observers could anticipate as almost inevitable the ultimate repudiation of the separate but equal formula. ${ }^{15}$ Professor Wright, although emphasizing that precedent is not dispositive of the decision in Brown, argues that the opinion should have included a more comprehensive review both of these cases and of cases prior to Plessy. ${ }^{16}$ Professor Bartley contends that the Sweatt and McLaurin decisions left prior doctrine with but a shadow of legality. He appears to regret that the Court relied upon historical, psychological, and sociological arguments and largely ignored what he considers a formidable body of precedent supporting its position. ${ }^{17}$

The approach adopted by these scholars assumes that the legitimacy of judicial action depends in some measure on the extent to which issues paralleling those which this action resolves have been similarly resolved in the context of earlier disputes. Although Professor Wechsler both unequivocally denied that departure from precedent was the source of his discontent with Brown ${ }^{18}$ and more generally refused to consider the judiciary bound by its mistakes, his plea for neutrality has been interpreted-or, probably more accurately, misinterpreted - as little more than an affirmation of the sanctity of stare decisis. ${ }^{19}$ Thus Judge Clark, who ends by urging the propriety of the unprincipled decision, states:

Perhaps I oversimplify, but the net result does appear to be that the principled

14. 339 U.S. 637 (1950); accord, Sipuel v. University of Okla., 332 U.S. 631 (1948); Missouri ex rel. Gaines v. Canada, 305 U.S. 337 (1938).

15. W. Murphy, Congress and the Court 80 (1962); Fortas, The Amendmemt and Equality Under Law, in The Fourteenth Amendient: Centennial Volume 100, 110-11 (B. Schwartz ed. 1970); Kamisar, Introduction to ARGUMENT: The OrAl ARGUMENT Before thiB SUPREME COURT IN BROWN v. BOARD OF EdUCATION OF TOPEKA, 1952-55 xiii, xiv-xvii (L. Friedman ed. 1969); Clark, Book Review, 36 U. CH1. L. REv. 239, $240-41$ (1968). See Fiss, Racial Imbalance in the Public Schools: The Constitutional Concepts, 78 Harv. L. Rev. 564, 606 (1965).

16. Wright, supra note 4, at 611 .

17. N. Bartiey, The Rise of Massive Resistance 6, 58 (1969).

18. Principles 31 ; see H. Wechsler, The Nationalization of Civil Liberties and Civil RiGHTS 22-23 (1970).

19. Velvel, Suggested Approaches to Constitutional Adjudication and Apportionment, 12 U.C.L.A.L. REv. 1381, 1387 (1965). 
decision is one which follows the beaten track rather closely, while a decision without precedent, breaking new ground, must be unprincipled. . . .

. . . [T] here is . . . a kind of pressure - even presumption - to choose what seems the side closest to precedent and past action. And that means a conservative vote for inaction and the status quo. It is a sad, but little noticed, fact that neutral principles eventually push to re-enforce the dead hand of the law and the rule of the past. ${ }^{20}$

This interpretation receives some support from the assertion by Professor Wechsler that precedent is not without importance and from his agreement with the statement of Justice Holmes that "imitation of the past, until we have a clear reason for change, no more needs justification than appetite."21 However, the result owes less to exegesis than to perceived logical necessity; if neutrality does not in part imply adherence to precedent many persons would contend that it lacks concrete content. Seeking the minimal attributes of neutrality, Professor Golding reasons:

1 fail to grasp Professor Wechsler's position if it consists in the statement that one ought to, or even can, supply "neutral principles" for "choosing" between competing values. $1 \mathrm{can}$, of course, choose between two competing values by reference to a third value which is more comprehensive or supreme, that is, when there is already an ordering of values. Assuming such an ordering, it seems to make sense to speak of "reasoned choice between competing values." . . . But it is difficult to see how the ordering itself is to be made on "neutral principles."

Perhaps, however, even lacking such an ordering of values, all is not lost for principled decision-making. . . .

Thus, when, in deciding a case, a tribunal is faced with two competing values and there is no good reason to be advanced for preferring one value over another, so that the preference given to one value is entirely arbitrary, if you please, we may still require that the tribunal formulate a standard or criterion that shall function as a principle of decision in this and other cases of its type. ...

It seems to me that the aspect of principled decision 1 have just described is not so remote from what Professor Wechsler demands of the Court in his appraisal of judicial review. ${ }^{22}$

This posited appropriateness of adherence to precedent and the

20. Clark, A Plea for the Unprincipled Decision, 49 VA. L. REv. 660, 664 (1963); see Countryman, supra note 4 , at 75-76.

21. O.W. Holmes, Holdsworth's English Law, in Collected Legal PaPers 285, 290 (1920); Principles 17.

22. Golding, Principled Decision-Making and the Supreme Court, 63 CoLuM. L. Rev. 35, 48-49 (1963). See also Abramson, Those Still Elusive Neutral Principles-A Further Groping, 7 DUQUESNE L. REv. 245, 246 (1968); Broiles, The Principles of Legal Reasoning, 17 MERCER L. REV. 389, 392-94 (1966). 
independence of such adherence from choice among competing values can be best explained in terms of the theory of games.

\section{Game Theory-Competitive and Coordinated Decisions}

A game is a set of rules delineating possible actions by individuals or groups and the consequences of such actions. The rules normally designate a set of players, define the behavioral choices open to the players and the information on which these choices must be based, and associate with each combination of choices an outcome comprising a payoff to each player. ${ }^{23}$ The prototypical dispute at law may be described in terms of the strictly competitive two-person game. In this game the players have diametrically opposed preferences: if one player prefers one outcome to another, the other player will prefer the other outcome; if one player is indifferent between two outcomes, the other player will also be indifferent. Likewise in the law, if, for example, a claim for damages is litigated the extent of the victory of the plaintiff usually measures the loss to the defendant.

Data concerning a game may be summarized diagramatically, as in Figure 1. In the game shown each player unless otherwise constrained may choose one of two courses of conduct: player A may

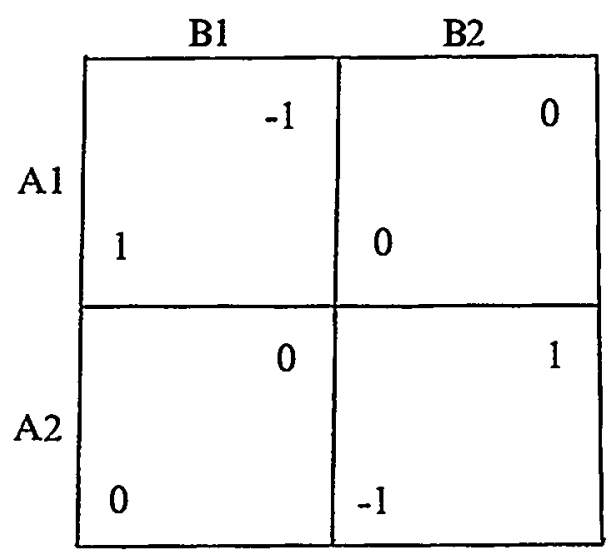

Figure 1

23. See generally M. Davis, Game Theory: A Nontechnical Introduction (1970); R. LUCE \& H. Raiffa, Games and Decisions: Introduction and Critical Survey (1957); J. von Neumann \& O. Morgenstern, Theory of Games and Economic Behavior (3d ed. I953); G. OWEN, GanE THEORY (1968). 
select either row 1 or row 2, while player B may select either column 1 or column 2 . The squares, representing the four possible combinations of choices, are marked with the payoffs to the players. The numbers in the lower left and upper right corners of a square indicate gain derived by players $A$ and $B$ respectively from the combination of choices associated with that square. Gain is most conveniently expressed in monetary units, dollars or perhaps thousands of dollars.

The choices of the players jointly determine which of the four sets of payoffs will be realized. Let player A select row 1 with probability $x$; then, since he must select either row 1 or row 2 , the probability that he will select row 2 is necessarily $1-x$. Similarly $y$ and $1-y$ may be introduced to designate the probabilities of selection of column $\mathrm{I}$ and of column 2 by player $B$. The expected payoffs to players A and B can be written as functions of the probabilities $x$ and $y:{ }^{24}$

$$
\begin{aligned}
& E_{\mathrm{A}}(x, y)=x+y-1 \\
& E_{\mathrm{B}}(x, y)=-x-y+1 .
\end{aligned}
$$

The strictly competitive nature of the relationship between the players is evident on calculation of the rate of change of the expected payoff to each player as the probabilities governing the actions of the players change:

$$
\begin{aligned}
& \frac{\partial E_{\mathrm{A}}}{\partial x}=\frac{\partial E_{\mathrm{A}}}{\partial y}=1 \\
& \frac{\partial E_{\mathrm{B}}}{\partial x}=\frac{\partial E_{\mathrm{B}}}{\partial y}=-1 .
\end{aligned}
$$

Because a change in either probability causes changes opposite in sign in the expected payoffs to the players one player must lose if the other gains. Both $x$ and $y$, being probabilities, must be non-negative and cannot exceed unity. Player $\mathrm{A}$ can maximize his gain by setting $x$ equal to unity without regard to the behavior of player B; similarly, player B can profit by setting $y$ equal to zero without regard to the

24. K. BORCH, THE ECONOMICS OF UNCERTAINTY 129-35 (1968). 
behavior of player A. Their combined actions produce the outcome of the upper right square: the pay off to each player if neither is constrained is zero units. Substitution of the values of $x$ and $y$ selected by players $A$ and $B$ respectively into equations (1) and (2) therefore yields:

$$
E_{\mathrm{A}}=E_{\mathrm{B}}=0
$$

Legal rules may be considered operators directly affecting either the probabilities $x$ and $y$ or the payoffs to the players. The law may be interpreted to prevent one player or the other from choosing a particular row or column; alternatively, where, for example, the law permits one player to recover damages if the other chooses a particular row or column, it may be thought to alter the consequences of this choice and thus to change $x$ or $y$ by indirection. The difficulty here is that the law in either granting or denying relief must choose to aid one player at the expense of the other. To reduce $x$ is to benefit $B$ but injure A; to raise $y$ is to benefit $A$ but injure $B$; to fail to do either is equivalently consequential. No rule applied to the game as presented can offer mutual advantage.

In his recent analysis of convention and its relationship to language, ${ }^{25}$ Professor Lewis elaborates a number of situations presenting a common problem-in each, gain to the individuals involved requires coordinated conduct. Motorists may drive on the right side of the road or on the left side of the road; which side is chosen is of little consequence so long as all drivers choose identically. Each of a group of persons wishing to meet but unable to communicate in any other way must try to anticipate where others will congregate. If a telephone conversation is cut off, one but not both of those persons interrupted ought to call to reestablish contact. Persons attending a party may seek to dress comparably although they do not care whether all wear formal or all wear informal attire. Oarsmen should row in unison; campers searching for firewood should not retrace the steps of their fellows. Those engaged in commerce gain by establishing a medium of exchange irrespective of the object chosen to be numeraire. Each oligopolist attempts to set prices approximately equal to the prices set by his competitors.

25. D. Lewis, Convention: A Philosophical Study (1969). See also de Saussure, On the Nature of Language, in Introduction to StructuralisM 43 (M. Lane ed. 1970). 
Language must be shared but one may otherwise arbitrarily associate sound and meaning. ${ }^{25}$

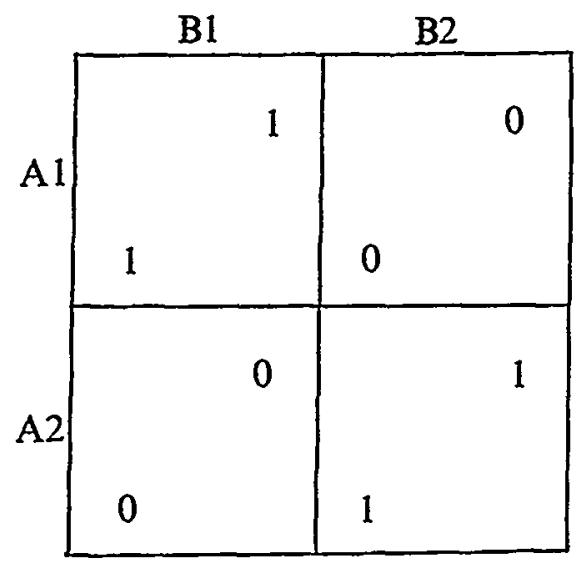

Figure 2

Reduced to its two-person analogue and thought typical of situations where coordination is appropriate, the problem confronting the motorist may be restated as the game shown in Figure 2. Here choice of row 1 by player $A$ or column 1 by player $B$ may be taken to indicate that the choosing player drives on the right side of the road, while choice of row 2 by player A or column 2 by player $B$ may be taken to indicate that the choosing player drives on the left side of the road. Again payoffs measure monetary benefit. If the players simultaneously choose to drive on the right side of the road or on the left side of the road, both gain one unit because each can go about his business without injury or delay; if they simultaneously select different sides of the road consequent collision negates this gain.

The expected payoffs to the players, in this instance algebraically identical, may as before be expressed in terms of the probabilities that player $A$ will choose row 1 and that player $B$ will choose row 2:

$$
E_{\mathrm{A}}(x, y)=E_{\mathrm{B}}(x, y)=2 x y-x-y+1 .
$$

The rates of change of the expected payoffs to the players as these probabilities are altered confirm a nonantagonistic interdependence because in every instance variation causes them undifferentiated gain or loss:

26. D. LEwIS, supra note 25 , at 5-8. 


$$
\begin{aligned}
& \frac{\partial E_{\mathrm{A}}}{\partial x}=\frac{\partial E_{\mathrm{B}}}{\partial x}=2 y-1 \\
& \frac{\partial E_{\mathrm{A}}}{\partial y}=\frac{\partial E_{\mathrm{B}}}{\partial y}=2 x-1 .
\end{aligned}
$$

If player $A$ believes that player $B$ is as likely to select column 1 as he is to select column 2 and player $B$ believes that player $A$ is as likely to select row 1 as he is to select row 2, both players are without guidcs to decision: $2 y-1$ and $2 x-1$, the terms which register the impact of their choices, reduce to zero. Independent manipulation of the probabilities $x$ and $y$ is without prospective advantage. The anticipated unresponsiveness of contemplated gain to individually patterned action is due to, but also reinforces, the unpredictability of conduct; as a result of randomized behavior, each player can expect to achieve only one-half of that benefit potentially available to him. Substitution of the suggested values of $x$ and $y$ into equation (6) yields:

$$
E_{\mathrm{A}}=E_{\mathrm{B}}=.5 \text {. }
$$

Were concerted action possible, $x$ and $y$ could together be set equal to either zero or unity to obtain:

$$
E_{\mathrm{A}}=E_{\mathrm{B}}=\mathrm{I} \text {. }
$$

Since those participating in games of the type discussed necessarily share any advantage, prevention of waste requires only salience. The players can be expected to coordinate their conduct if one set of actions stands out from the rest because it is unique in some conspicuous respect. Consistent achievement of a desired outcome is thus frequently feasible without formalized standards of behavior enforced through punishment of persons who do not adhere to them. One normally drives on the right side of the road in the United States and on the left side of the road in certain other countries not because one is subject to a penalty imposed by the state for failure to do so but because violation of an arbitrarily established traffic regulation can, independently of sanction, cause personal injury or property damage. 
Solutions to the other problems previously introduced are similarly conventional. Ideally all persons behave in particular ways, expect others to behave in ways consistent with them, and prefer to behave as they do on condition that others behave as expected. ${ }^{27}$

That achievement of desired equilibria may prove practicable even where no clear rule exists and the information of the players is otherwise sharply limited is evident from an experiment reported by Professor Schelling in which subjects were instructed to designate a meeting place in New York City. A majority of those questioned, apparently members of the Yale University community, selected the information booth at Grand Central Station; when asked to choose a time, almost all designated noon. ${ }^{28}$ In a parallel context Professor Lewis concludes: "The man in the song-'Standing on a corner with a dollar in my hand / Looking for a woman who's looking for a man' - is standing on that corner in conformity to a convention among all the local prostitutes and their customers." ${ }^{29}$

\section{The Neutrality of Precedent-Advantage to Litigants}

A scholar of the law in medieval France contended that a judge ought to be disqualified not only on such expected grounds as personal enmity toward a litigant or idiocy, but also for taking part in the prior decision of a similar case. The likelihood that he would decide the second case as he had decided the first was thought a source of bias sufficient to preclude his participation. ${ }^{30}$ The disregard of previously established principles implicit in this rule, while not without its modern equivalents, ${ }^{31}$ is historically atypical. The substantial respect normally accorded these principles is probably best expressed by Blackstone, who urged that "precedents and rules must be followed, unless flatly absurd or unjust; for though their reason be not obvious at first view, yet we owe such a deference to former times as not to suppose that they acted wholly without consideration." 32

27. Id. at $42-51,58,76,78-79$.

28. T. Schelling, The Strategy of Conflict 55-56 (1960).

29. D. LEWIS, supra note 25 , at 43 (emphasis in original).

30. J. Dawson, The Oracles of the LaW xv (1968).

31. H. COX, The Feast of Fools 34 (1969); J. Plumb, The Death of the Past 44 (1970).

32. 1 W. Blackstone, Commentaries $* 70$. See also Mirehouse v. Rennell, 5 Eng. Rep. 759, 774 (K.B. 1833). "Precedent has . . . always been the life-blood of legal systems, whether primitive, archaic or modern." D. LLOYD, INTRODUCTION TO JURISPRUDENCE 367 (rev. ed. 1965) (footnote omitted). 
The source of this respect has not been obvious. The argument that a rule which has stood the test of time is more likely to be advantageous than one which has not explains little because whether a rule has stood the test of time is often what must be resolved in the particular instance. ${ }^{33}$ That those who decided disputes in the past were wiser than those who decide disputes today is an inadequate basis for acquiescence in their rulings not only because it is implausible. The wisdom of previous judges is not an a priori truth and comprehensive evaluation of their work is seldom as economical or as reliable as judgment concerning a small part of it. ${ }^{34}$ To avoid relitigating each issue in every context in which it appears is indisputably convenient but appeal to this convenience does not adequately explain judicial practice. ${ }^{35}$ From the perspective of the revolutionary, the members of the legal profession may demand continuity in the law as a means of preserving those conditions which have allowed them to achieve relative eminence; although perhaps correct, this conclusion has little persuasive force independent of the widely rejected ideological presuppositions on which it rests. ${ }^{36}$

The significance of adherence to precedent may more profitably be stated in terms of the prominence which consistent selection affords one of several otherwise undifferentiated solutions to a problem of coordination:

Indeed, precedent is merely the source of one important kind of salience: conspicuous uniqueness of an equilibrium because we reached it last time. ${ }^{7}$

Salience in general is uniqueness of a coordination equilibrium in a preeminently conspicuous respect. The salience due to precedent is no exception: it is uniqueness of a coordination equilibrium in virtue of its preeminently conspicuous analogy to what was done successfully before. ${ }^{33}$

It does not matter why coordination was achieved at analogous equilibria in the previous cases. Even if it had happened by luck, we could still follow the precedent set. ${ }^{39}$

Each new action in conformity to the regularity adds to our experience of

33. But see Jackman v. Rosenbaum Co., 260 U.S. 22, $31-32$ (1922).

34. See Y.B. 36 Hen. 6, f. 25b, pl. 26 (1458).

35. Langbein, Modern Jurisprudence in the House of Lords: The Passing of "London Tramvays," 53 CORNell L. Rev. 807, 811 (1968).

36. Gerber \& McAnany, Punishment: Current Survey of Philosophy and Law, 11 ST. Louls U.L.J. 491, 504 (1967), reprinted in THE SOCIOLOGY OF PUNISHMENT AND CORRECTION 337, 338 (2d ed. N. Johnston, L. Savitz \& M. Wolfgang eds. 1970). See Wolff, On Violence, 66 J. PHIL. 601 (1969).

37. D. LEwis, supra note 25 , at 36.

38. $I d$. at 38.

39. Id. at 39 (emphasis in original). 
general conformity. Our experience of general conformity in the past leads us, by force of precedent, to expect a like conformity in the future. And our expectation of future conformity is a reason to go on conforming, since to conform if others do is to achieve a coordination equilibrium and to satisfy one's own preferences. ... Once the process gets started, we have a metastable self-perpetuating system of preferences, expectations, and actions capable of persisting indefinitely. ${ }^{10}$

This view of precedent not only explains its doctrinal importance but also suggests an approach to the puzzle of the principled decision.

Controversy concerning the concept of neutrality has, in large measure, focused on the relationship between this concept and judicial choice among competing values. At least on one level of analysis the patently designative function of precedent in the law permits adjudication with at most minimal recourse to value choices. That application of a principle causes loss to no individual may be thought a condition sufficient to assure the neutrality of that principle. However, if disputes at law must without exception be characterized as strictly competitive games, no legal principle can be neutral in this primitive sense. By definition, any judicial decision granting or refusing relief must benefit one player through sacrifice of the interests of the other player.

An alternative in conceptual terms is to focus attention on the considerations which determine the outcome of litigation rather than on the outcome itself. To the extent that promotion of specific values-inevitable in any case-occurs only incidentally through judicial action in obedience to precedent, a court may be thought to function in the context of a game of coordination rather than in the context of a strictly competitive game. Since in games of coordination all players share any loss or advantage, the decisions of a court can, to this extent, be considered neutral irrespective of the inability of the court legitimately to posit preference for the values which it ultimately implements. Professor Radbruch identified the creation and maintenance of legal certainty, peace, and order as the great task of judicial institutions. ${ }^{41} \ln$ this view legal rules are essentially a source of salience; the continuity which the law supplies through assured application of settled principles is both the foundation of its neutrality and its most significant contribution to the well-being of society.

Consideration of the neutrality of the decision to follow or to

40. Id. at $41-42$.

41. G. Radbruch, Legal Philosophy II8 (K. Wilk transl. 1950). 
depart from prior rulings demonstrates that this approach is not entirely satisfactory. Salience in the law can be achieved through means alternative to present practice. The possibility that the intuitively just result may offer a less ambiguous coordinative fulcrum than a set of ostensibly more concrete but often seemingly conflicting legal principles can be excluded only by observation in the particular instance. ${ }^{42}$ At the opposite extreme, a clear but arbitrary rule-for example a rule that the taller litigant must win-may provide a salient but otherwise unsatisfactory guide to resolution of disputes. Adjudicatory certainty cannot be absolute but must be qualified through those compromises necessary simultaneously to implement values inconsistent with it. ${ }^{43}$

The judicial inclination to perpetuate a current principle and thus to continue gains from coordination may or may not be reinforced by the pattern of payoffs dictated by that principle in a strictly competitive game between individual litigants or the classes whose interests they represent. When advantages anticipated from alteration of this pattern of payoffs are thought to outweigh the prospective cost of change in terms of loss of salience the principle will normally be repudiated. As a result, the value judgment banished at the primary stage of analysis is reasserted on a more abstract plane. Determination of the effect of precedent may of course itself be taken to involve a game of coordination; at this point, however, the regressive nature of the problem and its solution is evident.

In an analogous context Professor Bickel reasons from similar premises to a parallel conclusion. Commenting on the freedom of the Supreme Court to decide or to refrain from deciding a case he asserts:

... a neutral principle . . . is, for Mr. Wechsler, a rule of action that the Court must be prepared to apply unrelentingly and without compromise in all future cases to which it is relevant. . ...4

It follows that the techniques and allied devices for staying the Court's hand, as is avowedly true at least of certiorari, cannot themselves be principled in the sense in which we have a right to expect adjudications on the merits to be principled. They mark the point at which the Court gives the electoral institutions their head and itself stays out of politics, and there is nothing

42. Cf. F. Cohen, EThiCal Systems and Legal Ideals 34-35 (1933); Dworkin, The Model of Rules, 35 U. CH1. L. Rev. 14, 40 (1967); Rumble, American Legal Realism and the Reduction of Uncertainty, 13 J. PUB. L. 45, 46 (1964); Sartorius, The Doctrine of Precedent and the Problem of Relevance, 53 ARCHiv Für Rechrs-und SOzIAlphilosophIE 343, 358 (1967).

43. F. Castberg, Problems of legal Philosophy 74 (rev. ed. 1957).

44. A. Bickel, The Least Dangerous Branch: The Supreme Court at the Bar of Pormics 129 (1962). 
paradoxical in finding that here is where the Court is most a political animal. ...

But this is not to concede unchanneled, undirected, uncharted discretion. It is not to concede decision proceeding from impulse, hunch, sentiment, predilection, inarticulable and unreasoned. The antithesis of principle in an institution that represents decency and reason is not whim or even expediency, but prudence. ${ }^{15}$

His argument emphasizes the need at some level of analysis to sacrifice salience in order to achieve other goals and the improbability that the extent of this sacrifice can be meaningfully measured.

Even assuming that situations in which prior decisions should and should not be followed are clearly defined, the approach implies the necessity of value choices in formulating rules. Justifying adherence to precedent by reference to gains from coordination provides a ground for reducing the importance of discriminate balancing of competing interests when disputes are adjudicated in the absence of controlling authority. Undue attention to coordinative advantage in such circumstances may encourage the development of uncomplicated rules which achieve the heightened salience of the bright line only by sacrificing the appropriate responsiveness to the conflicting concerns of individual litigants. The arbitrariness of many rules of property law, ${ }^{46}$ for example, should not be extended to other fields where coordination is a relatively less significant legal function. Here again recourse to subjective criteria seems mandatory.

In preceding paragraphs I have attempted to explain the suggested neutrality of obedience to precedent in terms of a shift of judicial focus from a game involving choice among inconsistent values to one in which intervention offers advantage to all players. Two approaches to Brown v. Board of Education ${ }^{47}$ paralleling that which would seek to supply a basis in precedent for the decision of the Court present concomitant opportunities for application of the distinction between

45. Id. at 132-33.

46. Most zealous of all for certainty in the law are property lawyers, for a system of rules, precisely defined and invariably applied by the courts, is essential to the institution of private property. Let one judge in one case in a superior court depart from one of the traditional rules of common law or equity relating to property, he immediately creates a furore in the profession; for as a result of this one decision, which may be fair as between the parties, thousands of like titles are rendered doubtful, the intentions of many testators who assumed the old law are likely to be frustrated and future conveyances cannot be drafted with any confidence. F. DOWRICK, JUSTICE ACcording TO THE ENGLisH COMMON LAWYERS 187 (1961) (footnote omitted).

See also Vallejo v. Wheeler, 98 Eng. Rep. 1012, 1017 (K.B. 1774).

47. 347 U.S. 483 (1954). See text accompanying notes 6-21 supra. 
games of coordination and strictly competitive games. First, in the context of Brown, and in other situations, resort to prior rulings need not be sharply differentiated from reliance on other sources of salience not judicially created. Second, reexamination of the interests of the parties before the Court may be thought to reveal their unadmitted complementarity. In the remaining paragraphs of this section I propose briefly to examine these alternative approaches.

The considerations which support stare decisis are equally pertinent to the enforcement of externally established norms. Implementation of legislative and constitutional values may, from one vantage point, be understood in terms of the role of the courts in promoting salience necessary to cooperative benefit. To Professor Black the ruling in Brown follows immediately from the propositions that the equal protection clause of the fourteenth amendment must be read to prohibit state action which significantly disadvantages the Negro race and that segregation is disadvantageous in the prohibited sense..$^{48}$ Professor Kinoy argues a parallel position with equal vigor:

When racial segregation is understood as a "badge of servitude" and an obstacle to the achievement of the constitutionally promised status of freedom for the Negro, the hazy confusions of the Wechsler criticisms vanish. The right of the freedmen to be freed of the marks of the "inferior race" may not be constitutionally balanced against the "right" of white citizens to cling to the trappings of the "superior race." That question was settled, not in Brown v. Board of Educ., but in the Civil War and in the Thirteenth and Fourteenth Amendments themselves. ${ }^{.9}$

Use of the concept of coordination to explain judicial adherence to legislative and constitutional commands may nevertheless be thought an instance of analytic overkill because inquiry perhaps properly terminates with recognition that courts assert values presented to them because that is their function.

Professor Wright asks whether Professor Wechsler meant to imply that every member of the racial groups involved in Brown must emerge from litigation with his right of association unimpaired before action by the Court is to be considered defensible. ${ }^{50}$ Such an implication, while confirming a distaste for judicial intervention in the strictly competitive game, would deny the sufficiency of a solution

48. Black, The Lawfulness of the Segregation Decisions, 69 YALE L.J.42! (1960).

49. Kinoy, The Constitutional Right of Negro Freedom, 21 RuTGERs L. REv. 387, 430 n.139 (1967). See also Harper v. Virginia Bd. of Elections, 383 U.S. 663, 677-78 n.7 (1966) (dissenting opinion); Gould, Book Review, 39 U. DET. L.J. 624, 627 (1962).

50. Wright, supra note 4 , at 607 . 
involving simply a shift in focus from this game to the game of coordination conjoined to it. However, here also a parallel response may not be inappropriate. Professors Bickel and Black point out the possibility that injury did not occur, suggesting respectively that separate public schooling and that segregation in any form may cause loss to both races. ${ }^{51}$ Their assertions provide a basis-albeit a paternalistic one-for contending that the apparent conflict of associational values which troubled Professor Wechsler is illusory, and that the participants in the game before the Court were prevented by ignorance from achieving an otherwise available outcome advantageous to all.

51. A. Bickel, The Supreme Court and the Idea of Progress 120 (1970); Black, supta note 48, at 428. See also Principles 26-27, 34. 
.

. 